\title{
Identification of Environmental Health and Safety in Pasar Rakyat Kertha, Kesiman Kertalangu Village, Denpasar City
}

\author{
Ida Ayu Made Dwi Susanti *, Luh Putu Kirana Pratiwi \\ Agribusiness Study Program, Faculty of Agriculture, Mahasaraswati University Denpasar, Bali, Indonesia \\ * dwisusanti1989@unmas.ac.id
}

\begin{abstract}
A market is a place where sellers and buyers meet in buying and selling transactions. People's market is a traditional market. The people's market is one of the most obvious indicators of the economic activities of the people in an area. The implementation of safety and health in the work environment is not only intended for visitors but also employees (market managers), suppliers, and traders. This is because people's markets can be the main route for the spread of infectious disease outbreaks. People's markets have an important position to provide safe food. Public markets are influenced by the existence of upstream producers (suppliers of fresh ingredients), suppliers, vendors, consumers, managers, health-related officers, and community leaders. The healthy market is one of the structures in the development of the people's market.
\end{abstract}

Keywords: People's Market, Identification, Health, and Safety Environmental

\section{Introduction}

A market is a place where sellers and buyers meet in buying and selling transactions. The people's market is one of the most obvious indicators of the economic activities of the people in an area. The economic standard of life of the community can easily be seen from the activities at the local people's market. This is because the people's market has been proven to be able to survive and provide services for the needs of the crisis, even for low-income people. People's market is a traditional market. By [1] the term Traditional Market is read as People's Market.

In the people's market agribusiness system, it is included in the sub-system of supporting institutions. The supporting institution subsystem provides services for the upstream agro-industry subsystem, the downstream agribusiness subsystem, and the marketing subsystem so that the agribusiness system can run smoothly. The supporting institution subsystem consists of an infrastructure form and an organizational form [2]. The role of the people's market is not only as a service provider for other subsystems but also as a place to sell people's needs from food to clothing.

Thus, occupational safety and health in the people's market environment are very important to be implemented. The implementation of occupational safety and health is not only intended for visitors but also employees (market managers), suppliers, and traders. Public markets can be the main route for the spread of infectious disease outbreaks. People's markets have an important position to provide safe food. Public markets are influenced by the existence of upstream producers (suppliers of fresh ingredients), suppliers, vendors, consumers, managers, health-related officers, and community leaders.

The healthy market is one of the structures in the development of the people's market. Healthy market development is strategic as an effort to strengthen biosecurity in the food chain which will increase (i) improve food security from production to consumption, (ii) educate producers, suppliers, traders, consumers, and (iii) as a consequence, their awareness of risks will increase food safety. 
Kertha People's Market is one of the people's markets located in Denpasar City, namely in East Denpasar District. Kertha People's Market is a form of public market located in urban village areas. Kertha People's Market is a people's market that was established in 2007. The advantage of Kertha People's Market is that it is very strategically located on the side of the By-Pass I.B Mantra road which is the supporting infrastructure of Karangasem, Gianyar, and Klungkung [3]. Previously, Kertha People's Market was a market managed by the private sector by renting land in the Tanjung Bungkak Traditional Village.

However, after the rental contract was completed, Kertha People's Market has now been managed by the Tanjung Bungkak Traditional Village and has become a Village Market. As a market that was previously privately managed and has just become a village market, it is necessary to see how to implement occupational safety and health in the Kertha People's Market environment. Thus, this study aims to identify occupational safety and health in the Kertha People's Market environment.

\section{Material and Methods}

This location was taken on purpose (purposive) with the consideration that Kertha People's Market is a market located in a very strategic place, namely on Jl. Prof. Dr. Ida Bagus Mantra which is one of the routes between districts.

The existence of the traditional market proves that the concept of the traditional market is the oldest economic mechanism and makes the traditional market the economic pillar of a region. According to a regulation issued by the President of the Republic of Indonesia Number 112 of 2007 [4], traditional or Traditional Markets are markets that are built and managed by local, private, stateowned, and regional-owned enterprises, including cooperation between the government and the private sector, in the form of shops, kiosks, booths, and tents that are owned or managed by entrepreneurs through micro, small and medium enterprises and in the process of buying and selling goods and services through bargaining.

The data collected in this study include primary data and secondary data. Primary data is obtained directly by interview and observation through related parties. The secondary data required were obtained from relevant literature such as books, research journals, the internet, and reports related to this research.

Data collection methods were carried out through direct observation or observation, in-depth interviews, and distributing questionnaires to all parties involved in the research by filling in a list of questions (questionnaire) that had been previously provided by the researcher, literature study, and documentation.

The data analysis method used in this research is descriptive qualitative analysis. The qualitative descriptive analysis method is to process the resulting data through direct interviews and through secondary data that is thoroughly described [5]. In the qualitative descriptive analysis, researchers explore and or take pictures of social situations that will be studied thoroughly, broadly, and deeply.

\section{Results and Discussion}

Kertha People's Market was established under the status of private ownership (private) based on a permit from the Denpasar City Government - Denpasar City Planning \& Building Office. 6/2001, IMB No. 1528 of 2006 with a land area of approximately 16 are. Kertha People's Market stands on the land belonging to the Tanjung Bungkak Traditional Village. The deed of establishment of the 
market was approved by both parties (the first party - the tenant on behalf of Ir. I B Adi Wirawan, the second party, namely the manager of the Tanjung Bungkak Traditional Village) in front of a notary under the name Kertalangu People's Market with permission to rent until 2020.

The idea and capital in building the market came from Ir. I B Soerya who made him the owner and I. A Utami Pratiwi, ST as the head of the market and changed his name to Kertha People's Market. This name change is intended so that there is no misunderstanding that the Kertha Traditional Market is a village market [3]. Since September 2020, Kertha People's Market has changed ownership to the property of Tanjung Bungkak Village (Figure 1).

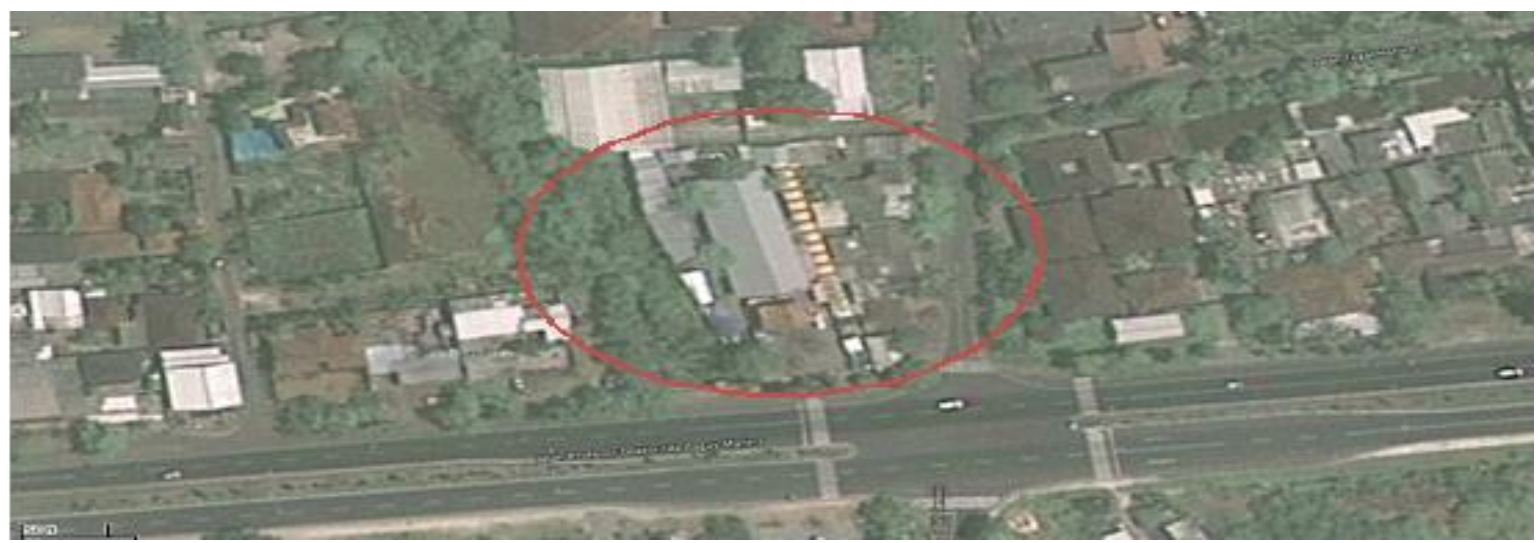

Figure 1. Kertha People's Market

Since its inception, Kertha Traditional Market has 9 stalls, 12 semikios, nudges, and 60 market tables, and 10 trading carts. The addition of rolling doors to kiosks and trade dividing lines at booths, semikios in the form of roofs, floors, and walls are modified by tenants (traders) according to their trading needs with the limit for displaying their merchandise as far as one meter from the semikios front floor. Access is available in the eastern and western parts of the market-leading to the rear area of the market, which can be passed by motorized vehicles, namely two-wheeled and four-wheeled vehicles. The parking area is located at the front of the market office and next to the front market. The access road to the market is completely covered with paving blocks (Figure 2).

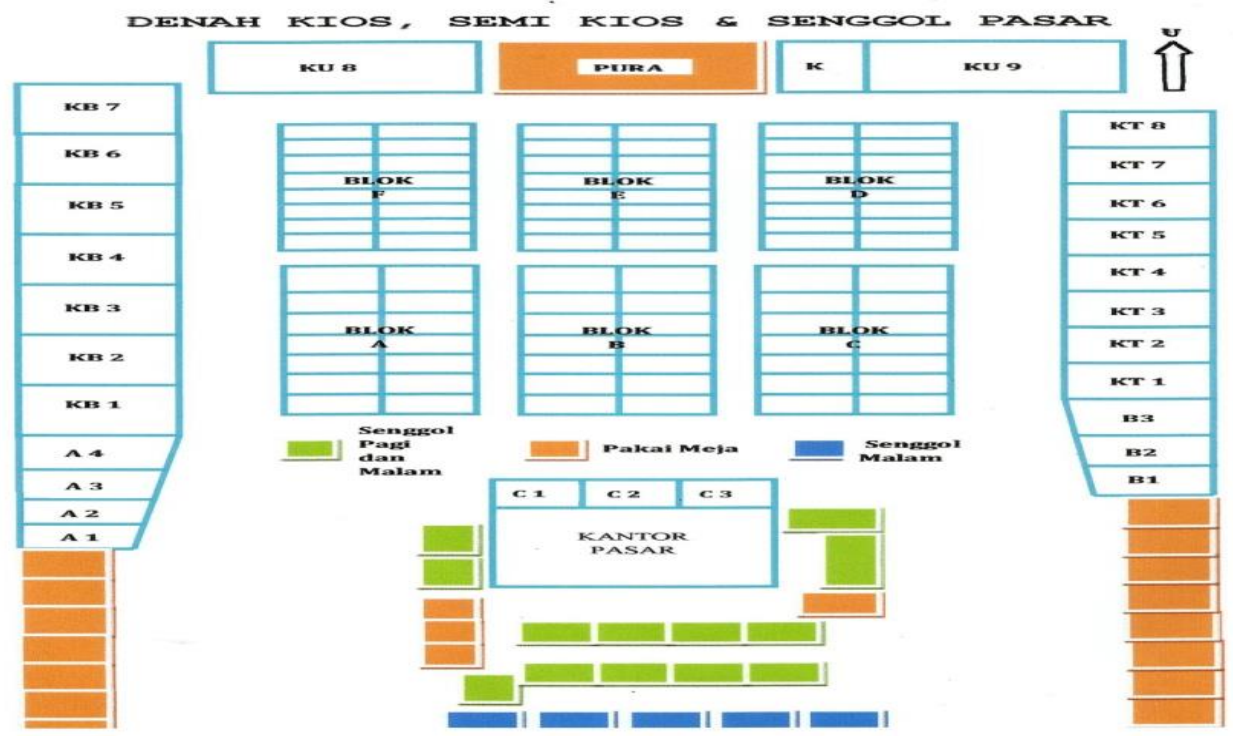

Figure 2. Kertha People's Market Plan 
Identification of Environmental Health and Safety in Pasar Rakyat Kertha, Kesiman Kertalangu Village, Denpasar City

This study uses a healthy market assessment variable issued by [6] and [7]. The data in this study were obtained through observation and interviews. Observations were made in the Kertha People's Market environment such as booths, kiosks, semi-kiosks, parking lots, and TPS. Interviews were conducted with market managers represented by the market administration department. The data in this study were analyzed using qualitative descriptive analysis. The results of this study can be seen as follows (Table 1).

Table 1

Identification of Environmental Health and Safety of Kertha People's Market

\begin{tabular}{|c|c|c|c|}
\hline \multirow{2}{*}{ No } & \multirow{2}{*}{ Substance Assessed } & \multicolumn{2}{|c|}{ Identification } \\
\hline & & Yes & No \\
\hline 1 & 2 & 3 & 4 \\
\hline $\mathbf{A}$ & Market Building & & \\
\hline 1 & Market buildings are well maintained & $\sqrt{ }$ & \\
\hline 2 & Clean market environment every day & $\sqrt{ }$ & \\
\hline 3 & The streets and alleys in the market have no trash scattered about & & $\sqrt{ }$ \\
\hline 4 & $\begin{array}{l}\text { The market does not smell, is not dark, is not stuffy, has vent/ventilation and } \\
\text { good lighting (not hot and bright) }\end{array}$ & $\sqrt{ }$ & \\
\hline 5 & The floor is non-cracked, flat, non-slip, and easy to clean & $\sqrt{ }$ & \\
\hline 6 & The floor has no standing water & $\sqrt{ }$ & \\
\hline 7 & $\begin{array}{l}\text { All materials and equipment used are put in place and not blocking the } \\
\text { road/alley }\end{array}$ & $\sqrt{ }$ & \\
\hline 8 & All market facilities are well maintained and clean & & $\sqrt{ }$ \\
\hline 9 & Market aisles are not used for selling & $\sqrt{ }$ & \\
\hline $\mathbf{B}$ & BUILDING & & \\
\hline 1 & Loyal stalls/cleaners and there is no trash scattered about & & $\sqrt{ }$ \\
\hline 2 & No garbage piling up and rotting & $\sqrt{ }$ & \\
\hline 3 & There is a table where to sell and clean conditions & $\sqrt{ }$ & \\
\hline $\mathbf{C}$ & GARBAGE DUMP & & \\
\hline 1 & Have a Temporary Trash Collection & $\sqrt{ }$ & \\
\hline 2 & TPS does not smell, there is no trash scattered about & $\sqrt{ }$ & \\
\hline 3 & Trash cans are available at each kiosk & $\sqrt{ }$ & \\
\hline 4 & There are trash bins in each of the market stands & & $\sqrt{ }$ \\
\hline 5 & There is a separation of wet and dry waste & & $\sqrt{ }$ \\
\hline D & WASTE AND DRAINAGE CHANNELS & & \\
\hline 1 & All sewage/drainage channels must be cemented and covered with metal grids & & $\sqrt{ }$ \\
\hline 2 & Smooth waste flow/drainage & & $\sqrt{ }$ \\
\hline 3 & $\begin{array}{l}\text { Sewers/drains in wet booths (fish, meat, cut poultry, major vegetables, grated } \\
\text { coconut) there is no stagnant water }\end{array}$ & & $\sqrt{ }$ \\
\hline D & TOILET & & \\
\hline 1 & Toilets are available for men and women and do not queue & & $\sqrt{ }$ \\
\hline 2 & The toilet is clean, does not smell, there are no mosquito larvae & $\sqrt{ }$ & \\
\hline 3 & Has vent/vent and enough light & & $\sqrt{ }$ \\
\hline 4 & There is enough water & $\sqrt{ }$ & \\
\hline 5 & There is a hand washing place equipped with soap & & $\sqrt{ }$ \\
\hline 6 & There is a person in charge of the maintenance and cleanliness of the toilet & $\sqrt{ }$ & \\
\hline $\mathbf{F}$ & CLEAN WATER & & \\
\hline 1 & There is a sufficient amount of water to flow smoothly & $\sqrt{ }$ & \\
\hline 2 & The water faucet is located in a strategic place and easy to reach & $\sqrt{ }$ & \\
\hline 3 & The water used must be clean, colorless, odorless, and tasteless & $\sqrt{ }$ & \\
\hline $\mathbf{G}$ & PLACE FOR SALES OF FOOD AND FOOD INGREDIENTS & & \\
\hline 1 & $\begin{array}{l}\text { In places where food and groceries are sold, there is a place for washing hands } \\
\text { with running water equipped with soap }\end{array}$ & & $\sqrt{ }$ \\
\hline 2 & $\begin{array}{l}\text { Tables/places where food and groceries are sold have a minimum height of } 60 \\
\mathrm{~cm} \text { from the floor }\end{array}$ & $\sqrt{ }$ & \\
\hline
\end{tabular}


Identification of Environmental Health and Safety in Pasar Rakyat Kertha, Kesiman Kertalangu Village, Denpasar City

\begin{tabular}{|c|c|c|c|}
\hline \multirow{2}{*}{ No } & \multirow{2}{*}{ Substance Assessed } & \multicolumn{2}{|c|}{ Identification } \\
\hline & & Yes & No \\
\hline 3 & $\begin{array}{l}\text { The chicken slaughterhouse is located in a special location outside the market } \\
\text { building }\end{array}$ & & $\sqrt{ }$ \\
\hline 4 & $\begin{array}{l}\text { The place where food and foodstuffs are sold are not made of rust-resistant } \\
\text { materials and are not made of wood }\end{array}$ & & $\sqrt{ }$ \\
\hline 5 & Cutting tools for food and food ingredients are not made of wood & & $\sqrt{ }$ \\
\hline 6 & $\begin{array}{l}\text { Cool water is available or use ice cubes for storage of fresh fish and cut meat } \\
\text { and poultry for sale }\end{array}$ & & $\sqrt{ }$ \\
\hline 7 & The presentation of merchandise is grouped according to type & $\sqrt{ }$ & \\
\hline 8 & Food samples were taken for laboratory examination by officers & $\sqrt{ }$ & \\
\hline 9 & For fast food traders, an anal swab was done by a health worker & & $\sqrt{ }$ \\
\hline $\mathbf{H}$ & PLACE FOR SALES OF FOOD AND FOOD INGREDIENTS & & \\
\hline 1 & $\begin{array}{l}\text { Loss of places where food and groceries are sold, there is a place to wash hands } \\
\text { with running water equipped with soap }\end{array}$ & & $\sqrt{ }$ \\
\hline 2 & $\begin{array}{l}\text { Tables/places where food and groceries are sold have a minimum height of } 60 \\
\mathrm{~cm} \text { from the floor }\end{array}$ & $\sqrt{ }$ & \\
\hline 3 & $\begin{array}{l}\text { The chicken slaughterhouse is located in a special location outside the market } \\
\text { building }\end{array}$ & & $\sqrt{ }$ \\
\hline I & PLACE FOR SALES OF FOOD AND FOOD INGREDIENTS & & \\
\hline 1 & $\begin{array}{l}\text { Loss of places where food and groceries are sold, there is a place to wash hands } \\
\text { with running water equipped with soap }\end{array}$ & $\sqrt{ }$ & \\
\hline 2 & $\begin{array}{l}\text { Tables/places where food and groceries are sold have a minimum height of } 60 \\
\mathrm{~cm} \text { from the floor }\end{array}$ & $\sqrt{ }$ & \\
\hline $\mathbf{J}$ & LIGHTING, TEMPERATURE, AND HUMIDITY & & \\
\hline 1 & Natural and artificial lighting is bright enough to carry onto the street & $\sqrt{ }$ & \\
\hline 2 & The temperature in each kiosk/booth is at least not hot and not stuffy & $\sqrt{ }$ & \\
\hline $\mathbf{K}$ & HAND WASHING FACILITIES & & \\
\hline 1 & There is a place for washing hands with sufficient amounts of running water & $\sqrt{ }$ & \\
\hline 2 & Equipped with soap, kept clean, and located in an easily accessible location & $\sqrt{ }$ & \\
\hline $\mathbf{L}$ & PARKING LOT & & \\
\hline 1 & $\begin{array}{l}\text { There is a parking space for two-wheeled, three-wheeled, four-wheeled vehicles } \\
\text { and a place for loading and unloading merchandise }\end{array}$ & $\sqrt{ }$ & \\
\hline 2 & The entry and exit paths are separated & & $\sqrt{ }$ \\
\hline 3 & The market entry and exit routes are separated & & $\sqrt{ }$ \\
\hline M & TRADERS/EMPLOYEES & & \\
\hline 1 & $\begin{array}{l}\text { Traders and/or employees use work clothes and personal protective equipment } \\
\text { (PPE) such as aprons, footwear, boots, hair coverings, gloves }\end{array}$ & $\sqrt{ }$ & \\
\hline 2 & There is a group or association of market traders & & $\sqrt{ }$ \\
\hline 3 & $\begin{array}{l}\text { There are training to improve the cleanliness, safety, and health of the market for } \\
\text { traders and managers }\end{array}$ & & $\sqrt{ }$ \\
\hline 4 & market in the last three months & & $\sqrt{ }$ \\
\hline 5 & Do not smoke when selling & & $\sqrt{ }$ \\
\hline 6 & Don't spit carelessly & & $\sqrt{ }$ \\
\hline 7 & $\begin{array}{l}\text { Traders of meat, fish and cut poultry and live poultry always wash their hands } \\
\text { with clean water and soap after touching their wares }\end{array}$ & & $\sqrt{ }$ \\
\hline No & VISITORS & & \\
\hline 1 & There are appeals/slogans for the visitor community & $\sqrt{ }$ & \\
\hline \multirow[t]{2}{*}{2} & $\begin{array}{l}\text { Visitors/buyers have a clean and healthy lifestyle (PHBS), for example: washing } \\
\text { hands with soap after touching fish, meat, cut poultry, live poultry, and cooked } \\
\text { food, not littering, not spitting carelessly, etc. }\end{array}$ & $\sqrt{ }$ & \\
\hline & AMOUNT & 32 & 27 \\
\hline $\mathrm{J}$ & TREATMENT COVID-19 & & \\
\hline 1 & Use a mask, face shield, and gloves during your activities & $\sqrt{ }$ & \\
\hline 2 & Visitors wear masks and maintain a distance of 1.5 meters & $\sqrt{ }$ & \\
\hline 3 & There is a place for washing hands, soap, and hand sanitizer & $\sqrt{ }$ & \\
\hline 4 & Spraying disinfectant on-site periodically every 2 days & & $\sqrt{ }$ \\
\hline
\end{tabular}


The water available at Kertha People's Market comes from groundwater so that the quality of clean water meets the requirements. The distance between the clean water source and the septic tank is more than 10 meters. Water testing has been carried out every 6 months by the East Denpasar District Health Office. Toilets at Kertha People's Market have a sufficient number of toilets but they are not separated between men's toilets and women's toilets.

Every hallway/booth has a trash can, but it is not divided into wet trash and dry rubbish. The trash can is not made of waterproof material and is not closed. Temporary garbage dumps are not waterproof, not easy to clean, and are not closed. It the located right in front of the main market route and the liquid waste does not flow smoothly so the cleaners have to encourage using running water.

Since the pandemic, Covid-19 managers have provided handwashing stations equipped with soap and running water. During Covid-19, market disinfection was carried out every 2 (two) times per month. In terms of safety, fire extinguishers are available, hydrants are not available, while there are security officers but there are no security posts and health service posts and first aid for accidents.

The environmental safety and health identification variable Kertha's Market shows that the number of Yes answers is 32. Thus, Kertha's Market is in the poor category $(\leq 37=\leq 64 \%)$. The follow-up to the results of the market assessment that has been carried out is that it is necessary to identify components that have not met the requirements for direct follow-up or through market managers to improve market conditions.

\section{Conclusion}

From the results of the above research, it can be concluded that market managers are still lacking in implementing safety and health in the Kertha People's Market environment. It is hoped that market managers can immediately implement environmental safety and health to tackle infectious disease outbreaks.

\section{References}

[1] Peraturan Menteri Perdagangan Republik Indonesia Nomor: 56/M-DAG/PEK/9/2014 Tentang Perubahan Atas Peraturan Menteri Perdagangan Nomor 70/M-DAG/PER/12/2013 Tentang Pedoman Penataan dan Membina Pasar Tradisional, Pusat Perbelanjaan dan Toko Modern.

[2] Antara, M. (2009). Pertanian Bangkit atau Bangkrut. Penerbit Arti Foundation? Denpasar. ISBN, 978979-1145-31-2.

[3] Susanti, I. D., Darmawan, D. P., \& Astiti, N. S. (2014). Strategi pengembangan pasar tradisional Kertha, Desa Kesiman Kertalangu, Kecamatan Denpasar Timur. Jurnal Manajemen Agribisnis, 2(1).

[4] Firmanzah dan R.E. Halim. (2012). Strategi Revitalisasi Pasar Tradisional. In: Basri, M.C., editor. Rumah Ekonomi Rumah Budaya. Jakarta: PT Gramedia Pustaka Utama.

[5] Prabowo, A., \& Heriyanto, H. (2013). Analisis pemanfaatan buku elektronik (e-book) oleh pemustaka di perpustakaan SMA Negeri 1 Semarang. Jurnal Ilmu Perpustakaan, 2(2), 152-161.

[6] Keputusan Menteri Kesehatan Republik Indonesia (2008). Tentang Pedoman Pengelolaan Pasar Sehat.

[7] Menteri Perdagangan Republik Indonesia (2020). Surat Edaran Nomor 12 Tahun 2020 tentang Pemulihan Kegiatan Perdagangan yang Dilakukan Selama Wabah Virus Corona 2019 (Covid-19) Pandemi dan Normal Baru. 